\title{
Bioactive Compound Variability in a Brazilian Capsicum Pepper Collection
}

\author{
Tanize dos Santos Acunha, Rosane Lopes Crizel, Icaro Borges Tavares, Rosa Lia Barbieri, \\ Claudio Martin Pereira de Pereira, Cesar Valmor Rombaldi, and Fabio Clasen Chaves
}

\begin{abstract}
This report aims to characterize the bioactive content of pepper (Capsicum L., Solanaceae) accessions from a Brazilian germplasm collection. Peppers are currently a major vegetable crop worldwide, with $31 \mathrm{Tg}$ produced in 2013, according to FAO. Seventytwo accessions of Capsicum annuum L., C. baccatum L., C. chinense Jacq., and C. frutescens $L$. were evaluated and high variability was observed in soluble solids, $\mathrm{pH}$, acidity, fruit color, total phenolic content, total carotenoid content, antioxidant potential, and capsaicinoid content. Accessions P119, P302, and P189 had the highest phenolic compound contents, which ranged from 225.16 to $243.47 \mathrm{mg}$ gallic acid equivalent $100 \mathrm{~g}^{-1}$. The highest antioxidant potential observed ranged from 2.71 to 3.03 mmol Trolox equivalent $100 \mathrm{mg}^{-1}$ in accessions P287, P50, and P25. Maximum carotenoid content was seen in accessions P269, P280, and $\mathrm{P} 179$, which contained between 53.42 and $54.11 \mathrm{mg} \beta$-carotene equivalent $100 \mathrm{~g}^{-1}$. Capsaicinoid content was highest in accessions $\mathrm{P} 120, \mathrm{P} 246$, and P236 and ranged from 6132.00 to $19,543.70 \mathrm{mg} 100 \mathrm{~g}^{-1}$. Capsaicin and dihydrocapsaicin represented, on average, $79 \%$ of the total capasaicinoid content. No one accession contained high levels of multiple bioactive compounds.
\end{abstract}

T.d.S. Acunha, R.L. Crizel, I.B. Tavares, C.V. Rombaldi, and F.C. Chaves, UFPel-FAEM, Dep. de Ciência e Tecnologia Agroindustrial, Campus Univ., Caixa Postal 354, CEP 96010-900, Pelotas, RS, Brasil; R.L. Barbieri, Embrapa Clima Temperado, Caixa Postal 403, CEP 96001-970, Pelotas, RS, Brasil; C.M.P. de Periera, UFPel-Centro de Ciências Químicas, Farmacêuticas e de Alimentos, Campus Univ., Caixa Postal 354, CEP 96010-900, Pelotas, RS, Brasil. Received 24 Aug. 2016. Accepted 4 Jan. 2017. ^Corresponding author (fabio. chaves@ufpel.edu.br). Assigned to Associate Editor Owen Hoekenga.

Abbreviations: DDPH, 2,2-diphenyl-1-picrylhydrazyl; FLD, fluorescence detector; GAE, gallic acid equivalents; HPLC, high performance liquid chromatography; QTOF, quadrupole time-offlight; SSC, soluble solids content; UHPLC, ultra-high performance liquid chromatography.

$\mathrm{B}$ RAZIL is a secondary center of diversity for Capsicum L. peppers, and many landraces are cultivated in small farms from north to south of the country. The genus Capsicum belongs to the Solanaceae family and contains more than 20 species, five of which (Capsicum annuum L., C. baccatum L., C. chinense Jacq., C. frutescens L., and C. pubescens Ruiz \& Pav.) are domesticated and grown commercially, primarily for culinary use in the food industry for their unique flavor, as a coloring and flavoring agent, and in the making of a variety of pepper-containing food products such as jellies, jams, and sauces. Additionally, oleoresin derived from Capsicum is used to produce pepper spray (Pino et al., 2007; Bae et al., 2012). In the last few years, the market for Capsicum has grown such that, in 2013, the world's Capsicum (chilies and fresh pepper) production reached 1.9 million ha and $>31 \mathrm{Tg}$ of harvested crop (FAOSTAT, 2016). Capsicum peppers may be sweet as with bell peppers or hot, like jalapeño and habanero. In hot Capsicum peppers, capsaicin $\left(\mathrm{C}_{18} \mathrm{H}_{27} \mathrm{NO}_{3}\right)$, derived from homovanillic acid, is the predominant pungent alkaloid (Appendino, 2008). In addition to capsaicinoids, the fruit of Capsicum is an important

Published in Crop Sci. 57:1-13 (2017).

doi: $10.2135 /$ cropsci2016.08.0701

(C) Crop Science Society of America 5585 Guilford Rd., Madison, WI 53711 USA All rights reserved. 
source of carotenoids (some with pro-vitamin A activity), flavonoids, ascorbic acid (vitamin C), and tocopherols (vitamin E) (Howard and Wildman, 2006). A number of health benefits have been associated with the compounds present in Capsicum peppers and include antioxidant, antimutagenic, and antitumor activities (Topuz and Ozdemir, 2007; Meghvansi et al., 2010; Zimmer et al., 2012). The development of cultivars rich in bioactive compounds has been cited as one of the main objectives of breeding programs (Lannes et al., 2007; Wahyuni et al., 2011). Therefore, the characterization of available germplasm is essential to increase conservation of genetic diversity and support breeding efforts (Hayano-Kanashiro et al., 2016). Brazilian germplasm collections conserve many accessions of Capsicum peppers, including landraces selected by farmers for several generations. However, in order for these accessions to become commercially available and be further explored, they need to be properly characterized (Rêgo et al., 2011; Padilha et al., 2015). The success of a breeding program is increased with germplasm characterization, particularly in terms of genetic variability. This study reports the chemical characterization of targeted specialized metabolites and groups of compounds present in Capsicum pepper accessions from a Brazilian genebank.

\section{MATERIALS AND METHODS Germplasm}

Fruit of 72 accessions of C. annuum, C. baccatum, C. chinense, and C. frutescens of the Embrapa Temperate Agriculture (Pelotas, RS, Brazil) germplasm collection were evaluated. Of these 72 genotypes, 51 were analyzed for total phenolic content, total carotenoid content, and antioxidant potential, and 40 were evaluated for capsaicinoid content (Table 1). Seeds from each genotype were obtained from plants grown under greenhouse conditions at Embrapa. Seedlings were transplanted to the field at the five- to seven-leaf stage in October in a randomized complete block design with three replicates and 72 treatments (genotypes). The experimental unit consisted of one row containing five plants of one genotype. Rows covered in black plastic were spaced $1.3 \mathrm{~m}$ apart, with plants spaced $0.5 \mathrm{~m}$ apart. Plants were irrigated by drip irrigation. Fruit from five plants per genotype from each replicate were harvested from February through May at the mature stage between 9:00 and 10:00 AM and pooled for a total of 216 samples. Seeds were removed and fresh fruit were evaluated for $\mathrm{pH}$, acidity, soluble solids, and color. The remaining fruit were stored at $-76^{\circ} \mathrm{C}$ for the other analyses. Each sample consisted of $10 \mathrm{~g}$ of fruit ground in liquid nitrogen in a ball mill (Marconi, MA350, Brazil).

\section{Analyses}

All analyses were performed in triplicate for each genotype replicate, and the mean of the three repeats was used for statistical analysis.
Table 1. Accessions of Capsicum (Solanaceae) analyzed for total phenolic content, total carotenoid content, antioxidant potential, and capsaicinoid content.

\begin{tabular}{|c|c|c|}
\hline Accession & Species & Color of mature fruit \\
\hline P9 & Capsicum baccatum & red \\
\hline P14 & Capsicum baccatum & red \\
\hline P25 & Capsicum baccatum & red \\
\hline $\mathrm{P} 27$ & Capsicum baccatum & yellow \\
\hline P28 & Capsicum baccatum & red \\
\hline P34 & Capsicum baccatum & red \\
\hline P46 & Capsicum annuum & red \\
\hline P49 & Capsicum baccatum & red \\
\hline P50 & Capsicum baccatum & yellow \\
\hline P59 & Capsicum baccatum & red \\
\hline P61 & Capsicum baccatum & yellow \\
\hline P72 & Capsicum chinense & red \\
\hline P76 & Capsicum annuum & yellow \\
\hline P79 & Capsicum baccatum & red \\
\hline P87 & Capsicum baccatum & red \\
\hline P89 & Capsicum baccatum & red \\
\hline P92 & Capsicum baccatum & red \\
\hline P100 & Capsicum annuum & red \\
\hline P103 & Capsicum baccatum & red \\
\hline P105 & Capsicum baccatum & red \\
\hline P108 & Capsicum baccatum & red \\
\hline P110 & Capsicum baccatum & yellow \\
\hline P116 & Capsicum chinense & pale yellow \\
\hline P117 & Capsicum baccatum & red \\
\hline P119 & Capsicum annuum & red \\
\hline P120 & Capsicum baccatum & red \\
\hline P169 & Capsicum baccatum & red \\
\hline P179 & Capsicum baccatum & red \\
\hline P189 & Capsicum annuum & red \\
\hline P197 & Capsicum baccatum & red \\
\hline P203 & Capsicum annuum & orange \\
\hline P213 & Capsicum baccatum & red \\
\hline P219 & Capsicum baccatum & red \\
\hline P235 & Capsicum baccatum & red \\
\hline P236 & Capsicum chinense & orange \\
\hline P239 & Capsicum baccatum & red \\
\hline P241 & Capsicum baccatum & red \\
\hline P242 & Capsicum chinense & pale orange \\
\hline P246 & Capsicum chinense & pale orange \\
\hline P258 & Capsicum annuum & red \\
\hline P259 & Capsicum annuum & yellow \\
\hline P269 & Capsicum chinense & red \\
\hline P270 & Capsicum baccatum & red \\
\hline P274 & Capsicum baccatum & orange \\
\hline P278 & Capsicum baccatum & red \\
\hline P280 & Capsicum baccatum & red \\
\hline P283 & Capsicum baccatum & red \\
\hline P284 & Capsicum baccatum & red \\
\hline P287 & Capsicum baccatum & red \\
\hline P295 & Capsicum chinense & red \\
\hline P302 & Capsicum annuum & red \\
\hline
\end{tabular}




\section{Soluble Solids, pH, Acidity, and Color}

Soluble solids content (SSC) was determined by refractometry (digital refractometer, Atago, PR-32 $\alpha$ ), and the results were expressed as a percentage $(\mathrm{w} / \mathrm{w})$. Acidity and $\mathrm{pH}$ were measured directly from the extracted fruit juice. Acidity was determined by titration and results were expressed as milligrams of citric acid per $100 \mathrm{~g}$ of fresh fruit $\left(\mathrm{mg} 100 \mathrm{~g}^{-1}\right)$. Skin color was measured with a colorimeter (Minolta, CR-300). Colors are specified in the CIE $L^{\star} a^{\star} b^{\star}$ system. The hue angle $\left({ }^{\circ} \mathrm{Hue}\right)$ was calculated using the formula ${ }^{\circ} \mathrm{Hue}=\tan ^{-1} b^{\star} / a^{\star}$. The $L^{\star}$ axis represents lightness, the $a^{\star}$ axis represents redness ranging from negative values for green to positive values for red, and the $b^{\star}$ axis represents yellowness ranging from negative values for blue to positive values for yellow.

\section{Total Phenolic Content, Total Carotenoid Content, and Antioxidant Potential}

Total phenolic content was determined using the Folin-Ciocalteau reagent. Two grams of ground fruit flesh without seeds was homogenized with $20 \mathrm{~mL}$ methanol for $1 \mathrm{~h}$ and centrifuged for $20 \mathrm{~min}$ at $5000 \mathrm{rpm}$ in a centrifuge refrigerated at $4^{\circ} \mathrm{C}$. A $250-\mu \mathrm{L}$ aliquot of the supernatant was diluted in $4 \mathrm{~mL}$ of water, and a control was also prepared containing $250 \mu \mathrm{L}$ of methanol. Both the samples and the control were combined with $250 \mathrm{~mL}$ of $0.25 \mathrm{~N}$ Folin-Ciocalteau reagent (Swain and Hillis, 1959). After $3 \mathrm{~min}$ of reaction, $500 \mathrm{~mL} 1 \mathrm{~N} \mathrm{Na}_{2} \mathrm{CO}_{3}$ were added, the mixture was incubated for $2 \mathrm{~h}$ at room temperature, and the absorbance was measured at $725 \mathrm{~nm}$ with results expressed as $\mathrm{mg}$ of gallic acid equivalents $100 \mathrm{~g}^{-1}$ of fruit fresh wt. (mg GAE $100 \mathrm{~g}^{-1}$ fresh wt.). Total carotenoid content was evaluated using the Association of Official Analytical Chemists method (970.64; AOAC, 2005) modified for the purpose of reducing the amount of sample used. One gram of ground fruit flesh was homogenized with $15 \mathrm{~mL}$ solvent extractor (hexane:ethanol:acetone:toluene at 10:6:7:7). Then aliquots of $1 \mathrm{~mL}$ of $10 \%$ methanolic potassium hydroxide were added and mixed for an additional $1 \mathrm{~min}$. The flasks were capped and placed in a $56^{\circ} \mathrm{C}$ water bath for $20 \mathrm{~min}$ and allowed to cool to room temperature for $1 \mathrm{~h}$. Aliquots of $15 \mathrm{~mL}$ hexane were pipetted into each flask. The flasks were brought to $50 \mathrm{~mL}$ with a $10 \%$ sodium sulfate solution. The flasks were shaken thoroughly and placed in a dark area for approximately $1 \mathrm{~h}$ to allow for phase separation. Absorbance was measured at $454 \mathrm{~nm}$ (spectrophotometer, JENWAY $6705 \mathrm{UV}-\mathrm{Vis}$ ) and results were expressed as micrograms of $\beta$-carotene equivalents per gram of fruit fresh wt. ( $\mu \mathrm{g} \beta$-carotene $\mathrm{g}^{-1}$ fresh wt.). Antioxidant potential was determined using the 2,2-diphenyl-1-picrylhydrazyl (DPPH) radical scavenging method (Brand-Williams et al., 1995). One hundred microliters of the methanolic fruit extract was added to $3.9 \mathrm{~mL}$ of DPPH solution in methanol $(100 \mathrm{mM})$. The solution was then stirred and kept in a closed flask in the dark. Absorbance was measured at $517 \mathrm{~nm}$ after $24 \mathrm{~h}$ of reaction. The antioxidant potential was expressed as millimoles of Trolox equivalent $100 \mathrm{mg}^{-1}$ fresh wt. (mmol Trolox $100 \mathrm{mg}^{-1}$ fresh wt.).

\section{Capsaicinoid Content by HPLC-FLD}

For the analysis of capsaicinoids, $300 \mathrm{mg}$ of lyophilized pepper fruit without seeds were extracted with $1 \mathrm{~mL}$ of acetonitrile and sonicated (sonicator, Unique, Ultracleaner 1400 A) for 10 min twice. The two extracts were combined, centrifuged (centrifuge, Eppendorf, 5430) for $5 \mathrm{~min}$ at 13,000 rpm, and filtered through a $0.2-\mu \mathrm{m}$ polytetrafluoroethylene membrane filter into an amber vial. Ten microliters of sample were injected in a high performance liquid chromatography (HPLC) (Thermo Scientific) equipped with a Luna C18 precolumn $(2.0 \times 4 \mathrm{~mm})$ and analytical column $(2.0 \times 150 \mathrm{~mm}, 100 \AA$, particle size $3 \mu \mathrm{m}$ ) from Phenomenex (Torrance) for chromatographic separation. Degassed solutions of acetic acid:ultrapure water $\left(1: 10^{3}, v / v\right.$, eluent A) and acetic acid:acetonitrile $\left(1: 10^{3}\right.$, $\mathrm{v} / \mathrm{v}$, eluent B) were used as mobile phase. The flow rate of the mobile phase was $0.2 \mathrm{~mL} \mathrm{~min}^{-1}$ using isocratic elution at $52 \%$ B. The column temperature was kept at $40^{\circ} \mathrm{C}$. Capsaicinoids were detected by fluorescence (at $\lambda \mathrm{Ex}=280 \mathrm{~nm}$ and $\lambda \mathrm{Em}$ $=354 \mathrm{~nm}$ ) and quantified by comparison with capsaicin and dihydrocapsaicin standards from Sigma-Aldrich.

\section{Capsaicinoid Identification by UHPLC-QTOF MS}

Ten microliters of the acetonitrile extract of genotypes P28 and P61 were injected in the ultra-high performance liquid chromatography (Shimadzu, Nexera) coupled to a high-resolution quadrupole time-of-flight (QTOF) mass spectrometer (maXis Impact). Capsaicinoids were separated using a Kinetex C18 column $(50 \times 2.1 \mathrm{~mm}, 1.7 \mu \mathrm{m}$; Phenomenex $)$, using a gradient of formic acid solution in water $(0.1 \% \mathrm{v} / \mathrm{v}, \mathrm{A})$, formic acid in acetonitrile $(0.1 \% \mathrm{v} / \mathrm{v}, \mathrm{B})$, with $2 \% \mathrm{~B}$ for $7 \mathrm{~min}$, followed by $98 \% \mathrm{~B}$ for $2 \mathrm{~min}$ and $2 \% \mathrm{~B}$ for $1 \mathrm{~min}$, for a total of $10 \mathrm{~min}$ at a flow rate of $0.4 \mathrm{~mL} \mathrm{~min}{ }^{-1}$. The mass spectrometer was operated in the electrospray ionization positive mode with a capillary voltage of $3500 \mathrm{~V}$, a nebulizer gas $\left(\mathrm{N}_{2}\right)$ pressure of two bars, drying gas at $10 \mathrm{~L} \mathrm{~min}^{-1}$, and a source temperature of $200^{\circ} \mathrm{C}$. The equipment was calibrated using sodium formate $(10 \mathrm{mM})$ covering an acquisition mass/charge $(\mathrm{m} / \mathrm{z})$ range from 50 to $1000 \mathrm{amu}$. The following protonated molecules were monitored: capsaicin $(m / z$ 306.2064), dihydrocapsaicin ( $m / z 308.2220)$, homocapsaicin $(m / z 320.2220)$, homodihydrocapsaicin $(m / z 322.2377)$, and nordihydrocapsaicin $(\mathrm{m} / z 294.2064)$.

\section{Statistical Analysis}

Data were analyzed for normality using Shapiro-Wilk's test, for homoscedasticity by Hartley's test, and the independence of residuals was graphically verified. Data were then analyzed using ANOVA $(p \leq 0.05)$. When significant, the effects were compared by LSD $(p \leq 0.05)$. Statistical analyses were performed using SAS software 9.2 (SAS Institute, 2008).

\section{RESULTS AND DISCUSSION}

High variability in soluble solids, $\mathrm{pH}$, acidity, color of fruit, total phenolic content, total carotenoid content, antioxidant potential, and capsaicinoid content was observed in the pepper accessions evaluated. 


\section{Compositional Variation}

Pepper fruit take $\sim 90 \mathrm{~d}$ from fruit set to maturity. They have an indeterminate pattern of production and seasonal variation in the rate at which maturation can occur. Peppers are generally harvested with at least $85 \%$ of the fruit surface having achieved the characteristic varietal color of red, yellow, or orange. There is also an associated increase in soluble solids and decrease in acidity at this stage (Lin and Saltveit, 2012). Total SSC of the studied genotypes varied from $5.8\left(\mathrm{P} 228, C\right.$. chinense) to $15.0^{\circ} \mathrm{Bx}(\mathrm{P} 9, C$. baccatum) and averaged $9.1 \pm 1.8$ (SD) (Table 2). In a study by Lannes et al. (2007) with 49 pepper accessions of $C$. chinense, SSC varied between 6 and $10^{\circ} \mathrm{Bx}$. An elevated SSC is of interest to the food industry since it is responsible for a higher fruit yield in food processing. Fruit acidity is another relevant technological parameter that determines the choice of thermal treatment applied during processing. In the Embrapa pepper collection evaluated, acidity varied from 0.1 (P161) to $0.6 \mathrm{~g}$ (P203) citric acid equivalents 100 $\mathrm{g}^{-1}$ of sample. Both extreme values occurred in genotypes of $C$. annuum, demonstrating within-species variability. Capsicum frutescens were on average more acidic than $C$. chinense and C. baccatum. $\mathrm{pH}$ varied from 5.2 (P100, C. annuиm) to 6.5 (P27, C. baccatum) and averaged $5.8 \pm$ $0.3 . \mathrm{pH}$ has an expected inversely proportional relation to acidity, where the higher the acid concentration, the lower the $\mathrm{pH}$. However, this is true only if the acids are found dissociated. Within the cell, acids are generally associated with potassium salts constituting buffer systems. The buffer capacity of some fruit allows for great variation in acidity without significant changes in $\mathrm{pH}$ (Powers and Shinholser, 1979). In addition to SSC, acidity, and $\mathrm{pH}$, color is another relevant parameter that influences fruit quality. Hue angle is determined by coordinates $a^{\star}$ and $b^{\star}$ and defines fruit color tone. Yellow, orange, and red were the characteristic colors observed in mature fruit in this germplasm collection. Among accessions evaluated, hue angle varied from 6.73 to $102.19^{\circ}$, which indicated that fruit color ranged from purplish red to light yellow.

In Capsicum peppers, carotenoids are the compounds responsible for fruit color (Duarte et al., 2004). Carotenoid content (Fig. 1 and 2) varied from 1.54 (P116, C. chinense) to $54.11 \mathrm{mg} \beta$-carotene $100 \mathrm{~g}^{-1}$ fresh wt. (P179, C. baccatum) and averaged $32.16 \pm 15.77 \mathrm{mg} \beta$-carotene
$100 \mathrm{~g}^{-1}$ fresh wt. Capsicum baccatum showed, on average, the highest carotenoid content when compared with the other species in this germplasm collection (Table 3). Rodriguez-Uribe et al. (2012) studied six cultivars of $C$. annuиm with orange-colored fruit and found carotenoid concentrations that ranged from 1 to $16 \mathrm{mg} 100 \mathrm{~g}^{-1}$. Although genetically similar, fruit composition may vary due to extrinsic factors such as biotic and abiotic stresses. While studying the chemical composition of 32 Capsicum accessions ( $C$. annuum, $C$. frutescens, $C$. chinense, and $C$. baccatum), Wahyuni et al. (2011) observed an average total carotenoid content of $\sim 40 \mathrm{mg} 100 \mathrm{~g}^{-1}$ fresh wt., similar to results found in this study. Padilha et al. (2015) found large variation for carotenoid content in Capsicum annum genotypes ranging from 1.5 to $147.7 \mathrm{mg} 100 \mathrm{~g}^{-1}$.

Regarding fruit phenolic compound content in the Embrapa accessions (Fig. 1 and 2), the concentration ranged from 54.4 (P179) to 243.47 (P189) mg of GAE $100 \mathrm{~g}^{-1}$. The genotypes with the highest and lowest phenolic compound contents were found in C. baccatum, and the grand mean of all accessions tested in this study was $122.08 \mathrm{mg}$ GAE $100 \mathrm{~g}^{-1}$. These results are in agreement with Bae et al. (2012), who reported fruit phenolic compound contents of 91 to $138 \mathrm{mg} 100 \mathrm{~g}^{-1}$ for Capsicum spp. Among species, the unidentified accessions of Capsicum spp. showed the highest mean phenolic compound content (200.53), followed by C. annuum (175.52), C. chinense (144.39), and C. baccatum (100.67) (Table 3). Perucka and Materska (2007) observed Capsicum pepper fruit phenolic contents that ranged from 37.54 to $67.35 \mathrm{mg} 100 \mathrm{~g}^{-1}$, which are closer to the lower end of the results found here.

Antioxidant potential of pepper fruit evaluated was found to vary from 0.5 to $3.0 \mathrm{mmol}$ Trolox $100 \mathrm{~g}^{-1}$ and averaged $1.3 \pm 0.7 \mathrm{mmol}$ Trolox $100 \mathrm{~g}^{-1}$. On average, $C$. annuum accessions had the highest antioxidant potential, followed by C. chinense (Table 3). Studies have shown a positive direct correlation between the antioxidant potential and the phenolic content of fruit (Bae et al., 2012). In this study, the observed correlation between antioxidant potential and Capsicum fruit phenolic content was very low $\left(R^{2}\right.$ $=0.1121)$. After removal of five outlying accessions (P25, $\mathrm{P} 287, \mathrm{P} 50, \mathrm{P} 100$, and P246) from the dataset, the correlation coefficient increased to 0.448 , which still does not indicate a direct relationship between the two variables in

Table 2. Physiochemical characteristics of 72 pepper genotypes grouped by species.

\begin{tabular}{|c|c|c|c|c|}
\hline Species & $\mathrm{pH}$ & Soluble solids & Acidity $†$ & Hue angle \\
\hline & & ${ }^{\circ} \mathrm{Bx}$ & $\mathrm{g}_{100 \mathrm{~g}^{-1}}$ & $\circ$ \\
\hline Capsicum annuum (14 accessions) & $5.7 \pm 0.3 b \neq$ & $9.7 \pm 1.6 \mathrm{a}$ & $0.29 \pm 0.1 b$ & $42.6 \pm 24.6 a b$ \\
\hline Capsicum baccatum (39 accessions) & $5.9 \pm 0.3 a$ & $9.0 \pm 1.9 \mathrm{ab}$ & $0.23 \pm 0.1 c$ & $35.6 \pm 20.9 b$ \\
\hline Capsicum chinense (16 accessions) & $5.8 \pm 0.2 \mathrm{ab}$ & $8.7 \pm 1.9 a b$ & $0.19 \pm 0.1 c$ & $58.8 \pm 27.2 a$ \\
\hline Capsicum frutescens (1 accession) & $5.7 \pm 0.0 b$ & $8.3 \pm 0.0 b$ & $0.42 \pm 0.0 a$ & $27.6 \pm 0.0 b$ \\
\hline Capsicum spp. (2 accessions) & $5.8 \pm 0.0 \mathrm{ab}$ & $9.7 \pm 1.4 \mathrm{a}$ & $0.22 \pm 0.1 \mathrm{c}$ & $38.9 \pm 30.4 b$ \\
\hline
\end{tabular}

$\dagger$ Expressed as grams of citric acid $100 \mathrm{~g}^{-1}$ of fruit on a fresh-weight basis.

$\ddagger$ Values are mean \pm standard deviation. Means followed by the same letter within a column are not significantly different at $p \leq 0.05$. 

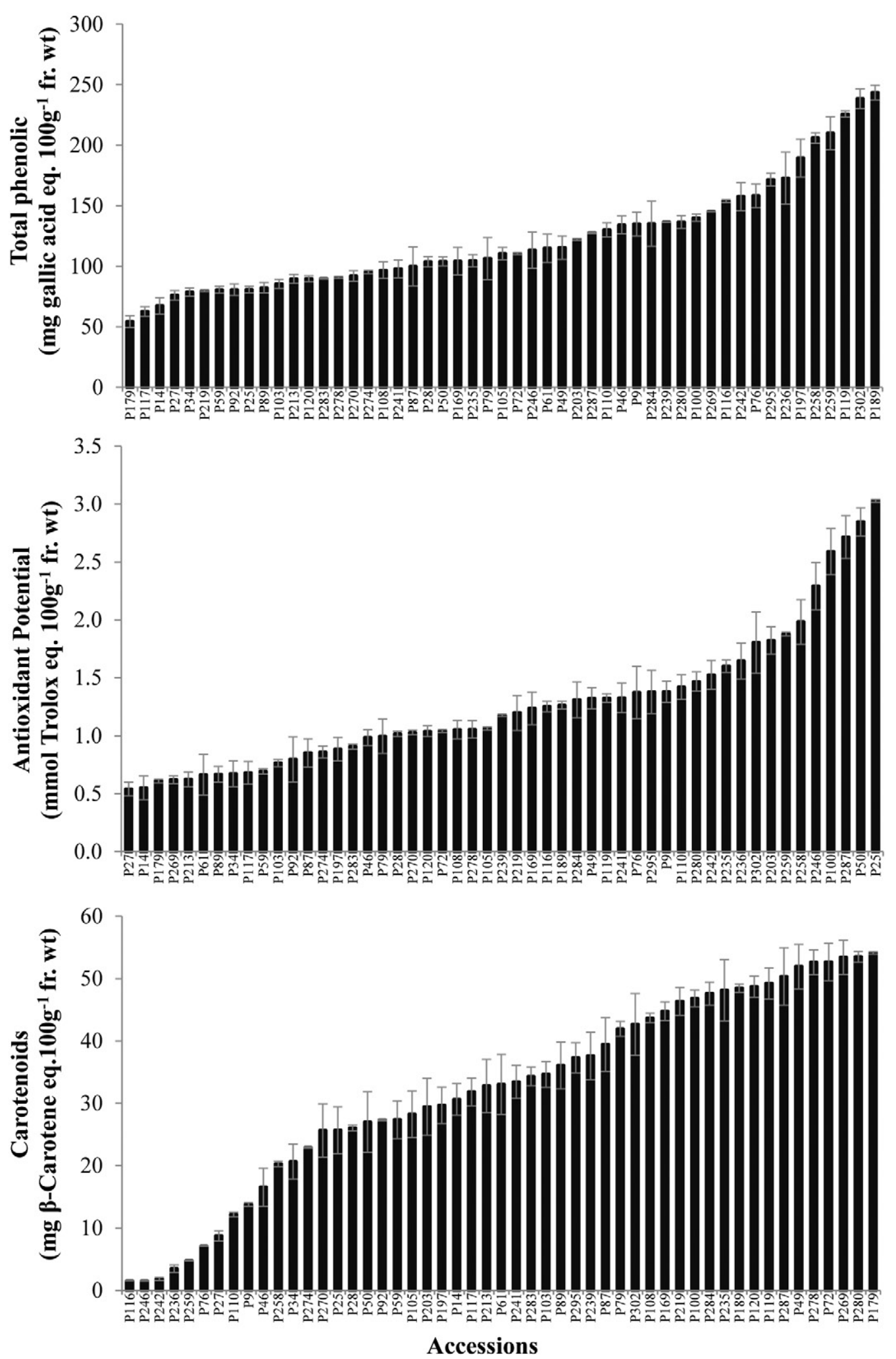

Fig. 1. Total phenolic content, antioxidant potential, and total carotenoid content of 51 pepper accessions (Capsicum spp.). Bars indicate standard error of the mean $(n=3)$. this study. Other compounds including ascorbic acid may have contributed more strongly to the observed antioxidant potential and therefore may explain the low correlation seen between antioxidant potential and phenolic content.

Consumers are looking for foods more nutritionally and functionally rich. On the other hand, growers are looking for more productive cultivars with improved tolerance to biotic and abiotic stresses. The breeders must take both requirements into consideration when developing new cultivars. In this study, the observed antioxidant potential and total phenolic content found for Capsicum genotypes is higher than those found in other commonly consumed vegetables and grains, including rice (Oryza sativa L.), beans (Phaseolus coccineus L.), beets (Beta vulgaris L.), carrots (Daucus carota L.), potatoes (Solanum tuberosum L.), and pumpkins (Cucurbita maxima Duch.) (Sreeramulu and Raghunath, 

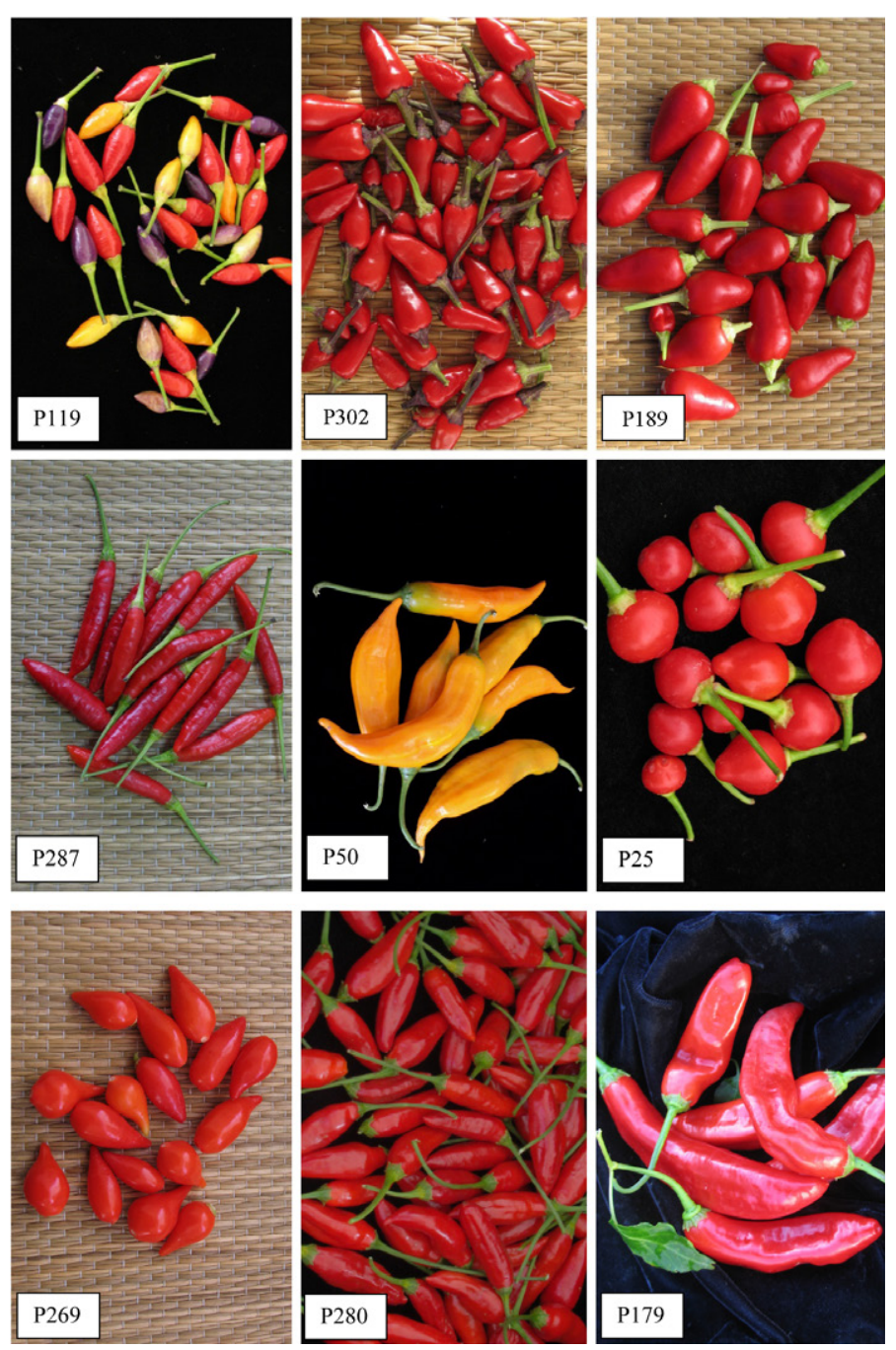

Fig. 2. Pepper accessions that showed the highest phenolic compounds content (P119, P302, and P189), the highest antioxidant potential (P287, P50, and P25), and the highest carotenoid content (P269, P280, and P179). Images: Rosa Lía Barbieri, Henrique Padilha, and Juliana Castelo Branco Villela.

2010). Phenolic compounds are important not only for their antioxidant potential but also for their antiallergenic (Chung and Champagne, 2008), antimicrobial (Viswanath et al., 2009), antithrombotic, and anti-inflammatory activities (Singh et al., 2009). There are numerous compounds with antioxidant potential capable of countering biological oxidative processes within the human body (Rahman et al., 2006). For example, carotenoids are among the compounds present in significant amounts in pepper with elevated antioxidant potential. Carotenoid content found in the studied germplasm collection was higher than that observed by Reif et al. (2013) for vegetables such as tomato (Lycopersicon lycopersicum L.) and carrots, widely known and recommended for consumption as being a rich source of carotenoids.

Although a specific daily-recommended intake for phytonutrients such as carotenoids and phenolic compounds does not currently exist, it is known that their consumption provides relevant health benefits beyond their antioxidative
Table 3. Mean total phenolic content (TP), antioxidant potential (AOP), and total carotenoid content (TC) of 51 pepper genotypes grouped by species.

\begin{tabular}{lccc}
\hline Species & TP† & AOP & TC \\
\hline & ${\mathrm{mg} 100 \mathrm{~g}^{-1}}$ & $\mathrm{mmol} 100 \mathrm{~g}^{-1}$ & ${\mathrm{mg} 100 \mathrm{~g}^{-1}}$ \\
Capsicum annuum & $175.52 \pm 44.2 \mathrm{ab}$ & $1.63 \pm 0.59 \mathrm{a}$ & $28.47 \pm 19.34 \mathrm{a}$ \\
Capsicum baccatum & $110.67 \pm 26.34 \mathrm{~b}$ & $1.14 \pm 0.61 \mathrm{~b}$ & $34.97 \pm 34.94 \mathrm{a}$ \\
Capsicum chinense & $144.39 \pm 30.61 \mathrm{~b}$ & $1.53 \pm 0.48 \mathrm{a}$ & $23.21 \pm 23.55 \mathrm{a}$ \\
Capsicum spp. & $200.53 \pm 60.73 \mathrm{a}$ & $1.39 \pm 0.19 \mathrm{ab}$ & $25.17 \pm 32.98 \mathrm{a}$ \\
\hline
\end{tabular}

† Total phenolic content expressed as milligrams gallic acid equivalents $100 \mathrm{~g}^{-1}$ of fruit on a fresh-weight basis.

‡ Antioxidant potential expressed as millimoles Trolox equivalent $100 \mathrm{~g}^{-1}$ fresh wt.

$\S$ Total carotenoid content expressed as milligrams $\beta$-carotene $100 \mathrm{~g}^{-1}$ fresh wt.

If Mean \pm standard deviation. Means followed by the same letter within a column are not significantly different at $p \leq 0.05$.

potential. Some carotenoids, for example, are also vitamin A precursors, an essential nutrient not produced by the human body but essential for growth and development, maintenance of epithelial tissues, reproduction, and proper functioning of the visual system in the regeneration of photoreceptors (Dutta et al., 2004) In another context, specialized metabolites serve as protection against stresses in plants (Schulze and Spiteller, 2009). For example, Park et al. (2012) reported the induction of polyphenol accumulation in C. annuum infected with the fungus Colletotrichum gloeosporioides (Penz.) Penz. \& Sacc., the causal agent of anthracnose disease and the major pathogen found in pepper. Another group of specialized metabolites with limited occurrence within Capsicum is the capsaicinoids. These are alkaloids that include capsaicin, dihydrocapsaicin, nordihydrocapsaicin, homocapsaicin, and homodihydrocapsaicin, among others, which are responsible for the characteristic pungency of Capsicum spp. (Kozukue et al., 2005). Whether these compounds play any role in plant defenses against pathogens or provide a fitness advantage under specific environmental conditions has not yet been established. Capsaicinoids have, however, been associated with anti-inflammatory and analgesic properties (Meghvansi et al., 2010; Zimmer et al., 2012).

\section{Method Optimization and Validation for Determination of Capsaicinoids Calibration Curve and Merit Figures}

Table 4 shows the parameters of the analytical curves for capsaicin and dihydrocapsaicin analyzed by HPLC with a fluorescence detector (FLD), with the respective concentration intervals and interday variation. Calibration curves had high linear coefficients $(R \geq 0.998)$ and similar interday sensitivity for both compounds. The limit of detection was $2.5 \mathrm{ng} \mathrm{mL} \mathrm{m}^{-1}$ for capsaicin and $0.6 \mathrm{ng} \mathrm{mL}^{-1}$ for dihydrocapsaicin, indicating that the optimized method has a good detection limit when compared with methods employed in other studies (Karnka et al., 2002; Juangsamoot et al., 2012). Limits of quantitation were $8 \mathrm{ng} \mathrm{mL} \mathrm{m}^{-1}$ for capsaicin and $3 \mathrm{ng} \mathrm{mL^{-1 }}$ for dihydrocapsaicin. The interday variation 
Table 4. Method validation parameters from the high performance liquid chromatography-fluorescence detector analysis of capsaicin and dihydrocapsaicin.

\begin{tabular}{|c|c|c|c|c|c|c|c|}
\hline \multirow[b]{2}{*}{ Analyte } & \multirow[b]{2}{*}{$\mathrm{CR}$} & \multicolumn{5}{|c|}{ Parameters $\dagger$} & \multirow{2}{*}{$\begin{array}{c}\text { Day to day } \\
\text { RSD }\end{array}$} \\
\hline & & $a$ & LD & $\mathrm{LQ}$ & $R^{2}$ & RSD & \\
\hline & 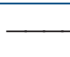 & 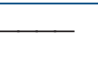 & $\longrightarrow$ & - & & $\longrightarrow$ & $\overline{-}$ \\
\hline Capsaicin & $1-10$ & 37031 & 2.38 & 7.95 & 0.998 & 0.19 & 0.28 \\
\hline Dihydrocapsaicin & $1-10$ & 94329 & 0.54 & 3.12 & 0.999 & 0.19 & 0.59 \\
\hline
\end{tabular}

† CR, concentration range; a, slope; LD, limit of detection; LQ, limit of quantification; $R^{2}$, linear regression coefficient; RSD, relative standard deviation.

was low, with a relative standard deviation of $0.28 \%$ for capsaicin and $0.59 \%$ for dihydrocapsaicin.

\section{Optimization of Extraction Solvent and Sonication Time}

Although different solvents are mentioned in the literature for the extraction of capsaicinoids, methanol (Antonious et al., 2009; Chinn et al., 2011; Wahyuni et al., 2011) and acetonitrile (Singh et al., 2009) are most frequently used. When comparing different solvents (methanol, acetone, and acetonitrile) for the extraction of capsaicinoids, acetonitrile was found to be the most efficient and allowed for extracts with higher purity compared with other solvents (Karnka et al., 2002). In this study, methanol and acetonitrile were tested for capsaicinoid extraction efficiency. Acetonitrile was found to be better than methanol for capsaicin and dihydrocapsaicin extraction (Fig. 3).

To improve solvent extraction, some techniques such as ultrasound (Wahyuni et al., 2011), heating (Chinn et al., 2011), or soxhlet (Peña-Alvarez et al., 2012) are employed. However, methods such as soxhlet have disadvantages when compared with ultrasound, since they require the use of a larger quantity of sample, solvent, and time of extraction (Peña-Alvarez et al., 2012). Moreover, higher temperatures can promote degradation of the target compounds.

Upon choosing acetonitrile as the extraction solvent, the effect of sonication for different time periods was tested and $10 \mathrm{~min}$ was found to be the optimal treatment duration (Fig. 4). Once the extraction conditions were

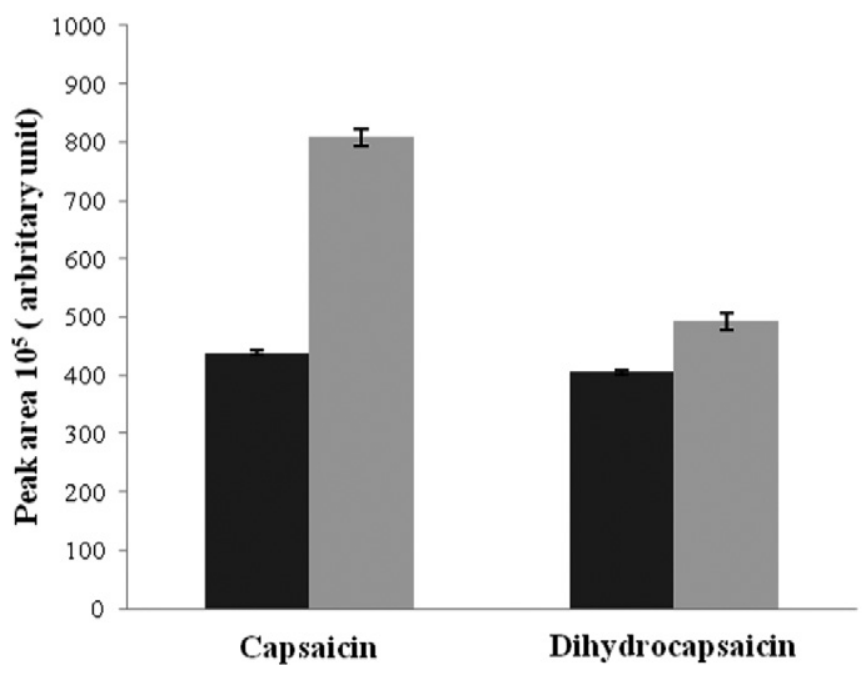

established, the samples were spiked with the standards to determine the recuperation yield that accounted for $75.7 \%$ for capsaicin and $79.8 \%$ for dihydrocapsaicin, with a relative standard deviation of 2.8 and $3.4 \%$, respectively.

\section{Capsaicinoid Analysis HPLC-FLD}

Capsaicin content of Capsicum accessions determined by HPLC-FLD ranged from $0.10 \mathrm{mg} 100 \mathrm{~g}^{-1}$ (P105, C. bacca-

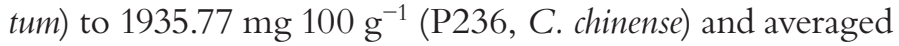
$191.4 \mathrm{mg} 100 \mathrm{~g}^{-1}$ of fruit on a dry-weight basis. The average capsaicin concentration found in Capsicum fruit studied here is on the same order of magnitude of that found for 16 Capsicum fruit from Nepal (Thapa et al., 2009), which had up to $1973 \mathrm{mg} 100 \mathrm{~g}^{-1}$ on a dry-weight basis. The large variability observed here was also seen in 63 accessions of C. chinense (Antonious et al., 2009), whereby the maximum value was 100 times greater than the minimum. When comparing among species (Table 5), on average, fruit of $C$. chinense showed the highest capsaicin concentration (640.81 mg $100 \mathrm{~g}^{-1}$ ), followed by C. aпnиит (229.09 $\mathrm{mg}$ $100 \mathrm{~g}^{-1}$ ) and C. baccatum (114.05 mg $100 \mathrm{~g}^{-1}$ ). Antonious and Jarret (2006) also reported a higher capsaicin concentration in C. chinense when compared with $C$. frutescens and $C$. baccatum. Capsicum annuum, on the other hand, had significantly lower capsaicin content than the other species tested $\left(0.93 \mathrm{mg} 100 \mathrm{~g}^{-1}\right)$. Dihydrocapsaicin content (Fig. 5) varied from 0.03 (P116) to $186.00 \mathrm{mg} 100 \mathrm{~g}^{-1}$ (P236), and the extreme values were found in $C$. chinense, while the average

Fig. 3. Comparison of the extraction potential of capsaicinoids using methanol and acetonitrile. Bars indicate standard error of the mean $(n=3)$. 


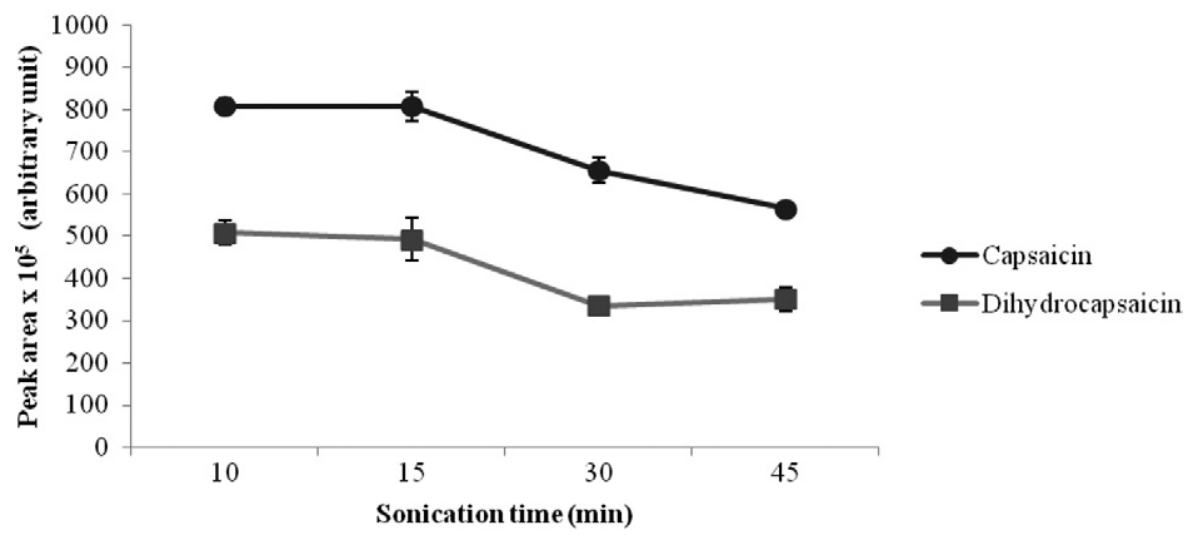

Fig. 4. Capsaicin and dihydrocapsaicin extracted with acetonitrile sonicated for different time periods. Bars indicate standard error of the mean $(n=3)$.

Table 5. Mean ( \pm SD) capsaicin and dihydrocapsaicin content of pepper accessions (Capsicum spp.).

\begin{tabular}{lcc}
\hline Species & Capsaicin & Dihydrocapsaicin \\
\cline { 2 - 3 } Capsicum annuum & $229.09 \pm 284.40 \mathrm{~b}$ & $50.55 \pm 59.23 \mathrm{a}$ \\
Capsicum baccatum & $114.05 \pm 162.86 \mathrm{~b}$ & $19.46 \pm 26.74 \mathrm{a}$ \\
Capsicum chinense & $640.81 \pm 888.71 \mathrm{a}$ & $64.33 \pm 84.89 \mathrm{a}$ \\
\hline
\end{tabular}

content of dihydrocapsaicin was $28.18 \mathrm{mg} 100 \mathrm{~g}^{-1}$. Similar to capsaicin content, $C$. chinense fruit had higher average dihydrocapsaicin content $\left(64.33 \mathrm{mg} 100 \mathrm{~g}^{-1}\right)$ than C. annuum

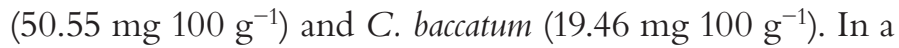
study of 11 Capsicum genotypes, Garcés-Claver et al. (2006) reported capsaicin concentrations ranging from 0.8 to 663.9 mg $100 \mathrm{~g}^{-1}$ and dihydrocapsaicin concentrations from 0.2

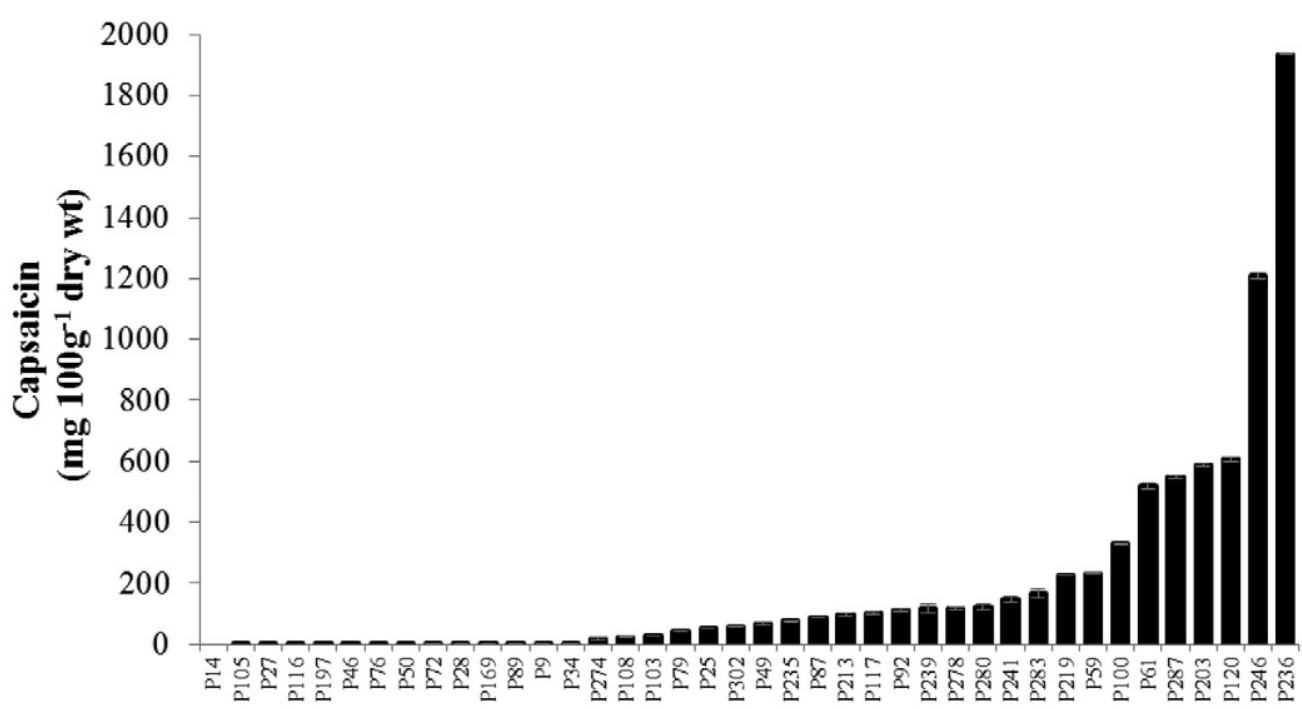

Fig. 5. Capsaicin and dihydrocapsaicin content of 40 pepper accessions (Capsicum spp.). Bars indicate standard error of the mean $(n=3)$.

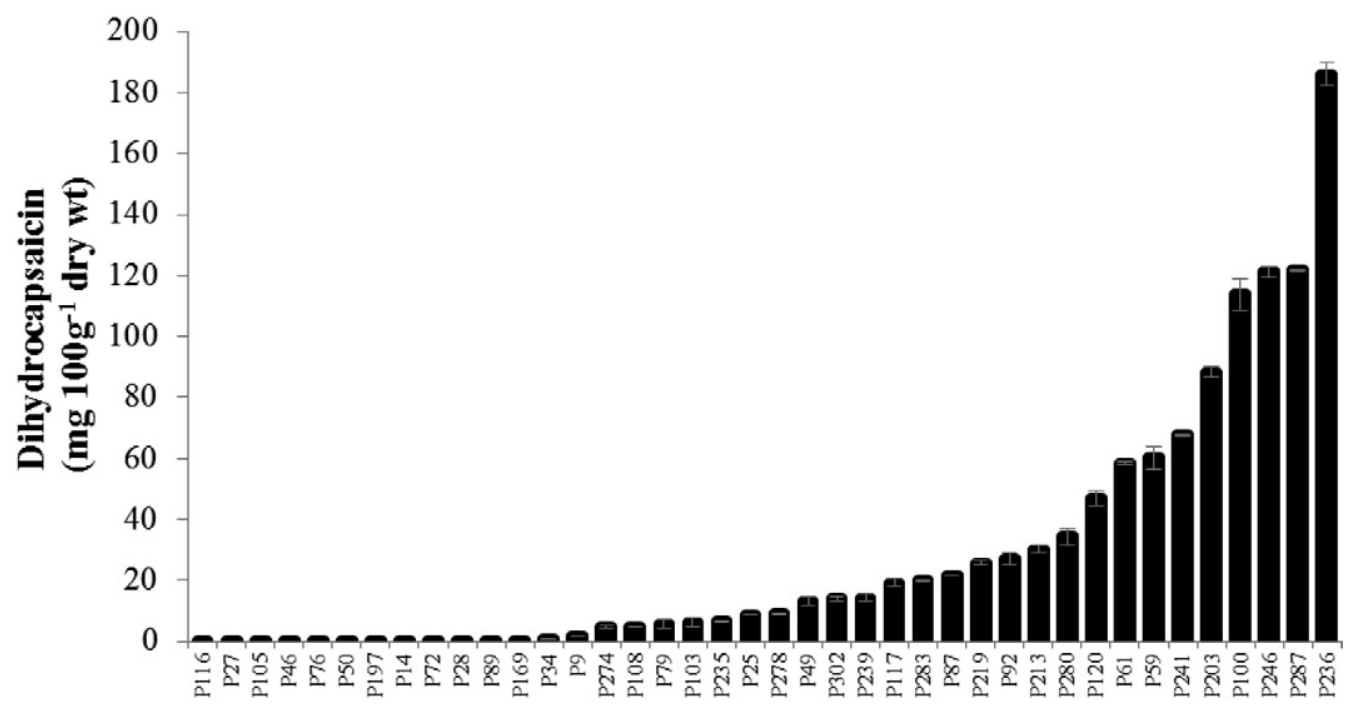

\section{Accessions}



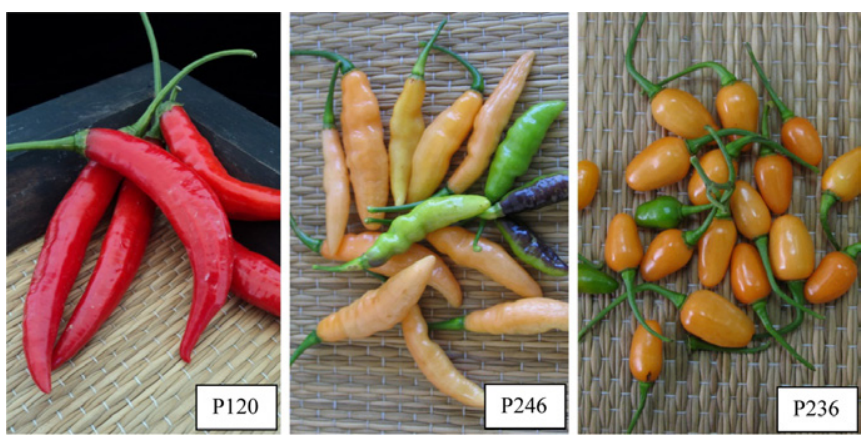

Fig. 6. Accessions with the highest capsaicinoid content. Images: Carla Sigales de Vasconcelos and Juliana Castelo Branco Villela.

to $372.7 \mathrm{mg} 100 \mathrm{~g}^{-1}$. Despite C. annuum being known as sweet and nonpungent, studies have demonstrated the presence of capsaicinoids in C. annuum fruit (Estrada et al., 2002; Garcés-Claver et al., 2006). Therefore, this species contains genotypes with and without pungency. This phenomenon may be related to possible changes in the genome during the evolution of the genus Capsicum caused, for example, by the action of retrotransposons, pieces of DNA able to move throughout the genome and alter genome structure and gene expression (Tam et al., 2009). Capsaicinoid variability, as well as variability of other metabolites in a germplasm collection, is desirable, demonstrating potential for the development of new cultivars that are more productive, adapted, tolerant to diseases, and have characteristics to satisfy the consumer, such as high bioactive compound content. In this study, genotypes P14, P105, and P27 (all genotypes of $C$. baccatum) are candidates to become lowpungency pepper cultivars since they showed the lowest concentration of capsaicinoids, which was a few thousand times less than the average of all genotypes evaluated. On the other hand, genotypes P236 (C. chinense), P246 (C. baccatum), and P120 (C. baccatum) showed the greatest potential to be developed into pungent cultivars (Fig. 6), with capsaicinoid concentration three times higher than the average.

\section{UHPLC-QTOF Mass Spectrometry}

To confirm the identity of the measured capsaicinoids, 2 of the 40 samples were also analyzed by UHPLCQTOF mass spectrometry. On the basis of the total ion chromatogram of each sample, some capsaicinoids were identified within a $5-\mathrm{mDa}$ error based on the exact mass of each compound. Five different capsaicinoids were identified: capsaicin, nordihydrocapsaicin, dihydrocapsaicin, homocapsaicin, and homodihydrocapsaicin (Fig. 7).

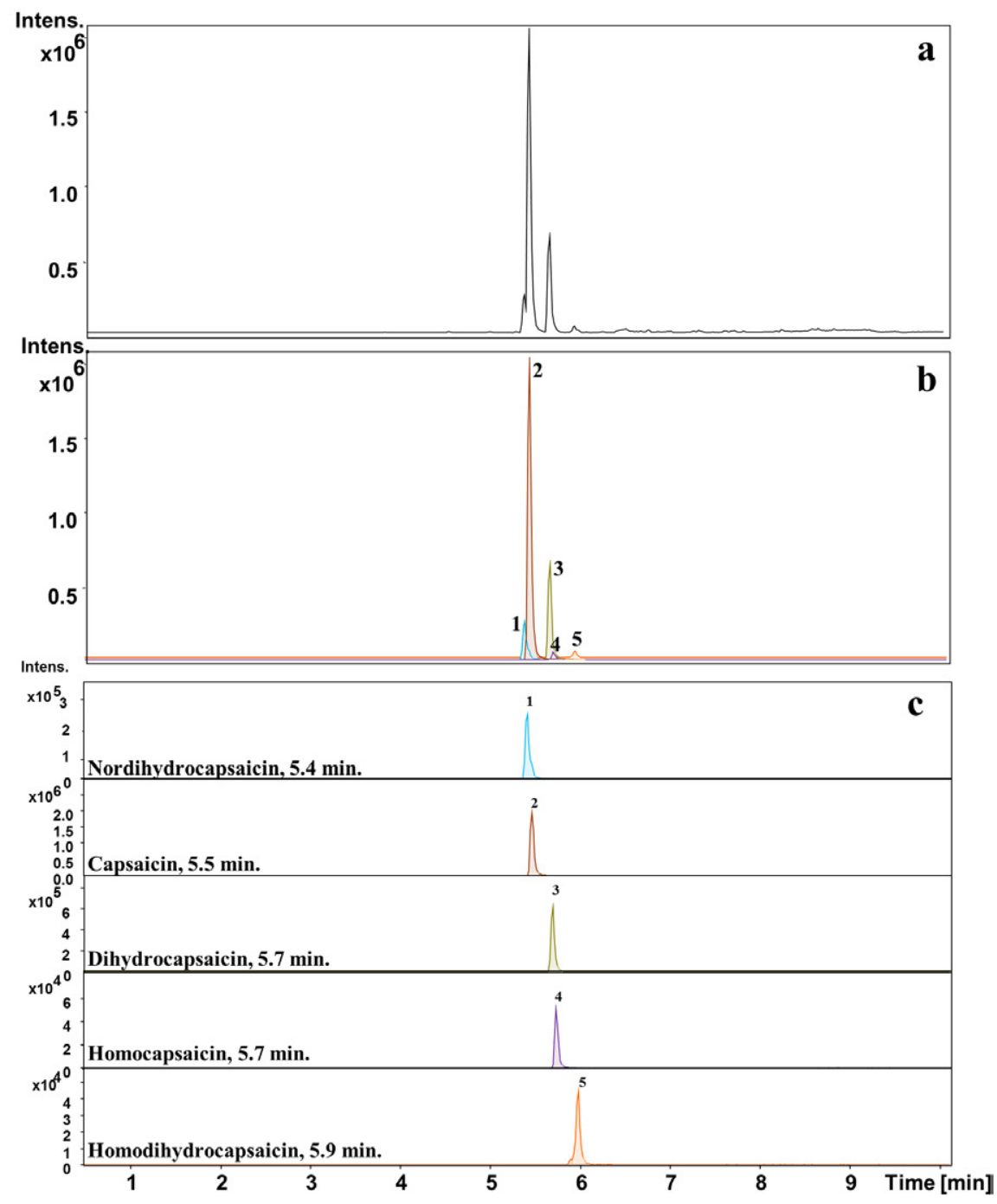

Fig. 7. (a) Total ion chromatogram and (b,c) extracted ion chromatograms of capsaicinoids extracted from Capsicum genotype P61. 
The mass spectra of the peak with retention time of 5.4 min showed a signal with $m / z 294.2069\left([\mathrm{M}+\mathrm{H}]^{+}\right.$: $\mathrm{C}_{17} \mathrm{H}_{28} \mathrm{NO}_{3}$ ) corresponding to the molecular ion and base peak at $m / z 293.1991$, indicating the presence of nordihydrocapsaicin, with an error of $1.9 \mathrm{ppm}$, compared with the theoretical spectrum (Fig. 8). The mass spectrum of the peak at retention time 5.5 min showed a molecular ion and base peak at $m / z 306.2068\left([\mathrm{M}+\mathrm{H}]^{+}: \mathrm{C}_{18} \mathrm{H}_{28} \mathrm{NO}_{3}\right)$, indicating the presence of capsaicin, with an error of $-1.4 \mathrm{ppm}$ compared with the theoretical spectrum of this compound (Fig. 8). The compounds with a retention time of 5.7 min showed mass spectra with a molecular ion and a base peak at $m / z 308.2218\left([\mathrm{M}+\mathrm{H}]^{+}: \mathrm{C}_{18} \mathrm{H}_{30} \mathrm{NO}_{3}\right)$ and $320.2231\left([\mathrm{M}+\mathrm{H}]^{+}: \mathrm{C}_{19} \mathrm{H}_{30} \mathrm{NO}_{3}\right)$, respectively, indicating the presence of dihydrocapsaicin and homocapsaicin, with errors of 0.6 and $-3.5 \mathrm{ppm}$ compared with the respective theoretical spectra (Fig. 8 and 9). The mass spectrum of the peak at retention time $6.0 \mathrm{~min}$ presented a base peak at $m / z 322.2380\left([\mathrm{M}+\mathrm{H}]^{+}: \mathrm{C}_{19} \mathrm{H}_{32} \mathrm{NO}_{3}\right)$ that confirmed homodihydrocapsaicin, with an error of $0.9 \mathrm{ppm}$ compared with its theoretical $m / z 322.2377$ (Fig. 9).

The chromatogram in Fig. 5 shows the retention time of the identified capsaicinoid nordihydrocapsaicin as being $5.4 \mathrm{~min}$, followed by capsaicin with a retention time of $5.5 \mathrm{~min}$, dihydrocapsaicin and homocapsaicin with a retention time of $5.7 \mathrm{~min}$, and homodihydrocapsacin with a retention time of $6.0 \mathrm{~min}$. Meanwhile, by HPLC-FLD, only two capsaicinoid peaks were observed that matched the retention time of the standards, capsaicin with a retention time of $8.3 \mathrm{~min}$ and dihydrocapsaicin with a retention time of $11.3 \mathrm{~min}$.

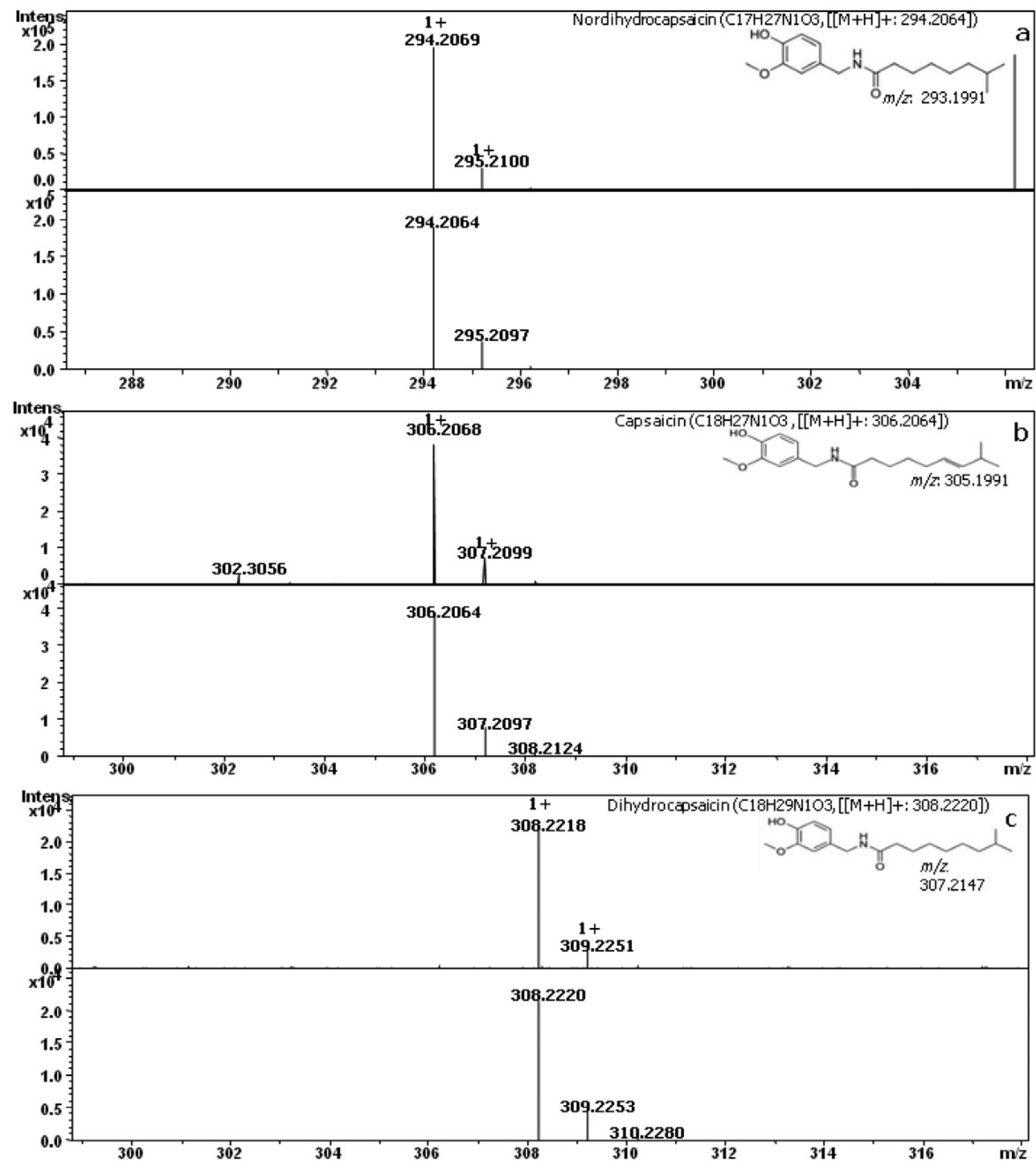

Fig. 8. Experimental and theoretical mass spectrum of (a) nordihydrocapsaicin, (b) capsaicin, and (c) dihydrocapsaicin. 


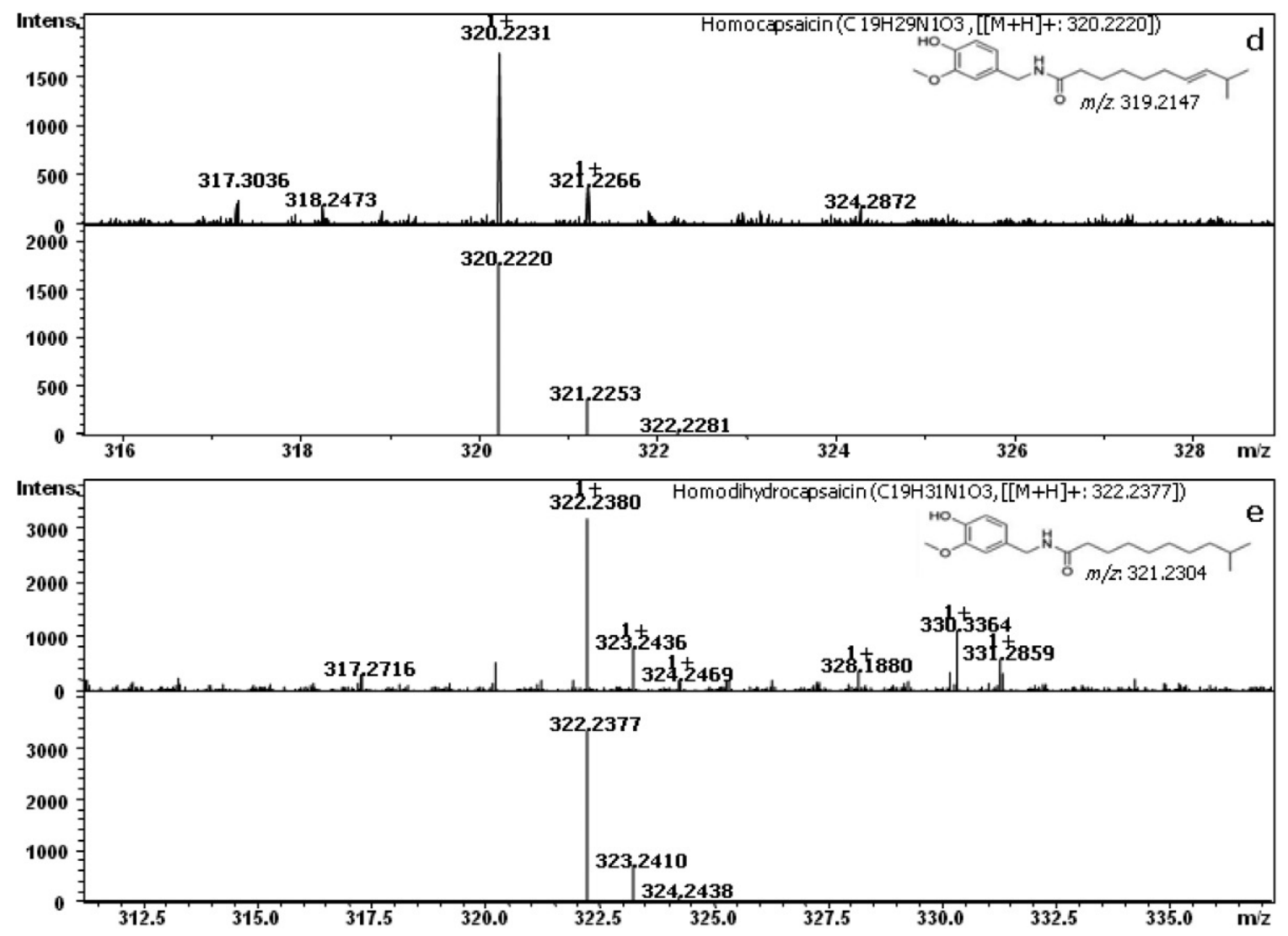

Fig. 9. Experimental and theoretical mass spectra of (d) homocapsaicin and (e) homodihydrocapsaicin.

Capsaicin and dihydrocapsaicin are considered the most pungent capsaicinoids and constitute up to $90 \%$ of the total capsaicinoid content found in peppers (Topuz and Ozdemir, 2007). In this study, capsaicin and dihydrocapsaicin, in a relative comparison with the other capsaicinoids found in the samples, accounted for $\sim 80 \%$ of total capsaicinoid content (Table 6).

\section{CONCLUSIONS}

Data presented here highlighted the variability of physicochemical parameters measured in Capsicum pepper and demonstrated the potential of individual accessions in the Embrapa Temperate Agriculture Capsicum germplasm collection for breeding efforts guided not only by agronomic

Table 6. Relative quantitation (\%) of capsaicinoids in pepper genotypes P28 and P61 analyzed by ultra-high performance liquid chromatography-quadrupole time-of-flight mass spectrometry.

Compound


characteristics but also by the bioactive compounds composition of the fruit for development of new cultivars.

The optimized extraction protocol for capsaicinoid analysis devised here was quick and simple, and the quantification method by HPLC-FLD showed low detection and quantitation limits for capsaicin $\left(2.5\right.$ and $\left.8 \mathrm{ng} \mathrm{mL}^{-1}\right)$ and dihydrocapsaicin ( 0.6 and $3 \mathrm{ng} \mathrm{mL} \mathrm{m}^{-1}$ ) and had high reproducibility with limited variation. Analysis with UHPLC-QTOF mass spectrometry allowed for unequivocal confirmation of the quantified capsaicinoids, as well as the identification of other minor capsaicinoids present in Capsicum pepper fruit.

\section{Acknowledgments}

To Dr. Luiz Fernando Arruda Santos for his assistance with the UHPLC-QTOF mass spectrometry analyses. Work was supported by SDECT-RS, CNPq, and CAPES.

\section{References}

Antonious, G.F., T. Berke, and R.L. Jarret. 2009. Pungency in Capsicum chinense: Variation among countries of origin. J. Environ. Sci. Health Part B 44:179-184. doi:10.1080/03601230802599118

Antonious, G.F., and R.L. Jarret. 2006. Screening Capsicum accessions for capsaicinoids content. J. Environ. Sci. Health Part B 41:717-729. doi:10.1080/03601230600701908

AOAC. 2005. Extraction of carotenes and xantophylls. Method no. 970.64. In: Official Methods of Analysis of the Association of Official Analytical Chemists, Arlington, VA. 18th ed. AOAC, Gaithersburg, MD. p. 1048-1049.

Appendino, G. 2008. Capsaicin and capsaicinoids. In: E. Fattorusso and O. Taglialatela-Scafat, editors, Modern alkaloids: Structure, isolation, synthesis, and biology. Wiley-VCH, Germany. p. 73-103.

Bae, H., G.K. Jayaprakasha, J. Jifon, and B.S. Patil. 2012. Extraction efficiency and validation of an HPLC method for flavonoid analysis in peppers. Food Chem. 130:751-758. doi:10.1016/j. foodchem.2011.07.041

Brand-Williams, W., M.E. Cuvelier, and C.L.W.T. Berset. 1995. Use of a free radical method to evaluate antioxidant activity. LWT--Food Sci. Technol. 28:25-30.

Chinn, M.S., R.R. Sharma-Shivappa, and J.L. Cotter. 2011. Solvent extraction and quantification of capsaicinoids from Capsicum chinense. Food Bioprod. Process. 89:340-345. doi:10.1016/j.fbp.2010.08.003

Chung, S., and E.T. Champagne. 2008. Using phenolic compounds to reduce the allergenic properties of peanut extracts and peanut butter slurries. J. Allergy Clin. Immunol. 121(2):S249. doi:10.1016/j.jaci.2007.12.985

Duarte, C., M. Moldão-Martins, A.F. Gouveia, S.B. da Costa, A.E. Leitão, and M.G. Bernardo-Gil. 2004. Supercritical fluid extraction of red pepper (Capsicum frutescens L.). J. Supercritical Fluids 30155-161. doi:10.1016/j.supflu.2003.07.001

Dutta, D., U.R. Chaudhuri, and R. Chakraborty. 2004. Structure, health benefits, antioxidant property and processing and storage of carotenoids. Afr. J. Food Agric. Nutr. Dev. 4:1510-1520.

Estrada, B., M.A. Bernal, J. Díaz, F. Pomar, and F. Merino. 2002. Capsaicinoids in vegetative organs of Capsicum annuum L. in relation to fruiting. J. Agric. Food Chem. 50:1188-1191. doi:10.1021/jf011270j
FAOSTAT. 2016. FAOSTAT database. FAO, Rome. http://www. fao.org/faostat/en/\#data/QC (accessed 3 Dec. 2016).

Garcés-Claver, A., M.S. Arnedo-Andrés, J. Abadía, R. GilOrtega, and A. Álvarez-Fernández. 2006. Determination of capsaicin and dihydrocapsaicin in Capsicum fruits by liquid chromatography-electrospray/time-of-flight mass spectrometry. J. Agric. Food Chem. 54(25):9303-9311. doi:10.1021/ jf0620261

Hayano-Kanashiro, C., N. Gámez-Meza, and L.A. Medina-Juárez. 2016. Wild pepper Capsicum annuum L. var. glabriusculum: Taxonomy, plant morphology, distribution, genetic diversity, genome sequencing, and phytochemical compounds. Crop Sci. 56:1-11. doi:10.2135/cropsci2014.11.0789

Howard, L.R., and R.E.C. Wildman. 2006. Antioxidant vitamin and phytochemical content of fresh and processed pepper fruit (Capsicum annum). In: R.E.C. Wallace, editors, Handbook of nutraceuticals and functional foods. CRC Press, Boca Raton, FL. p. 165-185. doi:10.1201/9781420036695.ch13

Juangsamoot, J., C. Ruangviriyachai, S. Techawongstien, and S. Chanthai. 2012. Determination of capsaicin and dihydrocapsaicin in some hot chilli varieties by RP-HPLC-PDA after magnetic stirring extraction and clean up with C18 cartridge. Int. Food Res. J. 19:1217-1226.

Karnka, R., M. Rayanakorn, S. Watanesk, and Y. Vaneesorn. 2002. Optimization of high-performance liquid chromatographic parameters for the determination of capsaicinoid compounds using the simplex method. Anal. Sci. 18:661-665. doi:10.2116/analsci.18.661

Kozukue, N., J.S. Han, E. Kozukue, S.J. Lee, J.A. Kim, K.R. Lee et al. 2005. Analysis of eight capsaicinoids in peppers and pepper-containing foods by high-performance liquid chromatography and liquid chromatography-mass spectrometry. J. Agric. Food Chem. 53:9172-9181. doi:10.1021/ jf050469j

Lannes, S.D., F.L. Finger, A.R. Schuelter, and V.W. Casali. 2007. Growth and quality of Brazilian accessions of Capsicum chinense fruits. Sci. Hortic. (Amsterdam) 112:266-270. doi:10.1016/j. scienta.2006.12.029

Lin, W.C., and M. Saltveit. 2012. Greenhouse production. In: V.M. Russo, editor, Peppers: Botany, production and use. CABI, Cambridge, MA. p. 57-71. doi:10.1079/9781845937676.0057

Meghvansi, M.K., S. Siddiqui, M.H. Khan, V.K. Gupta, M.G. Vairale, H.K. Gogoi, and L. Singh. 2010. Naga chilli: A potential source of capsaicinoids with broad-spectrum ethnopharmacological applications. J. Ethnopharmacol. 132:1-14. doi:10.1016/j.jep.2010.08.034

Padilha, H.K.M., E.S. Pereira, P.C. Munhoz, M. Vizzotto, R.A. Valgas, and R.L. Barbieri. 2015. Genetic variability for synthesis of bioactive compounds in peppers (Capsicum annuum) from Brazil. Food Sci. Technol. 35:516-523.

Park, S., W.Y. Jeong, J.H. Lee, Y.H. Kim, S.W. Jeong, G.S. Kim et al. 2012. Determination of polyphenol levels variation in Capsicum annuum L. cv. Chelsea (yellow bell pepper) infected by anthracnose (Colletotrichum gloeosporioides) using liquid chromatography-tandem mass spectrometry. Food Chem. 130:981-985. doi:10.1016/j.foodchem.2011.08.026

Peña-Alvarez, A., L.A. Alvarado, and L.E. Vera-Avila. 2012. Analysis of capsaicin and dihydrocapsaicin in hot peppers by ultrasound assisted extraction followed by gas chromatography-mass spectrometry. Instrum. Sci. Technol. 40:429-440. doi:10.1080/10739149.2012.679719 
Perucka, I., and M. Materska. 2007. Antioxidant vitamin contents of Capsicum annuum fruit extracts as affected by processing and varietal factors. Acta Sci. Pol. Technol. Aliment. 6:67-74.

Pino, J., M. González, L. Ceballos, A.R. Centurión-Yah, J. Trujillo-Aguirre, L. Latournerie-Moreno, and E. Sauri-Duch. 2007. Characterization of total capsaicinoids, colour, and volatile compounds of habanero chilli pepper (Capsicum chinense Jack.) cultivars grown in Yucatan. Food Chem. 104:16821686. doi:10.1016/j.foodchem.2006.12.067

Powers, J.J., and K. Shinholser. 1979. pH and buffering capacity of canned green peppercorns. J. Food Sci. 44:1788-1789. doi:10.1111/j.1365-2621.1979.tb09144.x

Rahman, I., S.K. Biswas, and A. Kode. 2006. Oxidant and antioxidant balance in the airways and airway diseases. Eur. J. Pharmacol. 533:222-239. doi:10.1016/j.ejphar.2005.12.087

Rêgo, E.R., M.M. Rêgo, C.D. Cruz, F.L. Finger, and V.W.D. Casali. 2011. Phenotypic diversity, correlation and importance of variables for fruit quality and yield traits in Brazilian peppers (Capsicum baccatum). Genet. Resour. Crop Evol. 58:909-918. doi:10.1007/s10722-010-9628-7

Reif, C., E. Arrigoni, H. Schärer, L. Nyström, and R.F. Hurrell. 2013. Carotenoid database of commonly eaten Swiss vegetables and their estimated contribution to carotenoid intake. J. Food Compos. Anal. 29:64-72. doi:10.1016/j. jfca.2012.10.005

Rodriguez-Uribe, L., I. Guzman, W. Rajapakse, R.D. Richins, and M.A. O'Connell. 2012. Carotenoid accumulation in orange-pigmented Capsicum annuum fruit, regulated at multiple levels. J. Exp. Bot. 63:517-526. doi:10.1093/jxb/err302

SAS Institute. 2008. The SAS system for Windows. Release 9.2. SAS Inst., Cary, NC.

Schulze, B., and D. Spiteller. 2009. Capsaicin: Tailored chemical defence against unwanted "frugivores". ChemBioChem 10:428-429. doi:10.1002/cbic.200800755

Singh, S., R. Jarret, V. Russo, G. Majetich, J. Shimkus, R. Bushway, and B. Perkins. 2009. Determination of capsinoids by HPLC-DAD in Capsicum species. J. Agric. Food Chem. 57:3452-3457. doi:10.1021/jf8040287
Sreeramulu, D., and M. Raghunath. 2010. Antioxidant activity and phenolic content of roots, tubers and vegetables commonly consumed in India. Food Res. Int. 43:1017-1020. doi:10.1016/j.foodres.2010.01.009

Swain, T., and W.E. Hillis. 1959. The phenolic constituents of Prunus domestica. I.-The quantitative analysis of phenolic constituents. J. Sci. Food Agric. 10:63-68. doi:10.1002/ jsfa. 2740100110

Tam, S.M., V. Lefebvre, A. Palloix, A.M. Sage-Palloix, C. Mhiri, and M.A. Grandbastien. 2009. LTR-retrotransposons Tnt1 and T135 markers reveal genetic diversity and evolutionary relationships of domesticated peppers. Theor. Appl. Genet. 119:973-989. doi:10.1007/s00122-009-1102-6

Thapa, B., N. Skalko-Basnet, A. Takano, K. Masuda, and P. Basnet. 2009. High-performance liquid chromatography analysis of capsaicin content in 16 Capsicum fruits from Nepal. J. Med. Food 12:908-913. doi:10.1089/jmf.2008.0187

Topuz, A., and F. Ozdemir. 2007. Assessment of carotenoids, capsaicinoids and ascorbic acid composition of some selected pepper cultivars (Capsicum annuum L.) grown in Turkey. J. Food Compos. Anal. 20:596-602. doi:10.1016/j.jfca.2007.03.007

Viswanath, V., A. Urooj, and N.G. Malleshi. 2009. Evaluation of antioxidant and antimicrobial properties of finger millet polyphenols (Eleusine coracana). Food Chem. 114:340-346. doi:10.1016/j.foodchem.2008.09.053

Wahyuni, Y., A.R. Ballester, E. Sudarmonowati, R.J. Bino, and A.G. Bovy. 2011. Metabolite biodiversity in pepper (Capsicum) fruits of thirty-two diverse accessions: Variation in healthrelated compounds and implications for breeding. Phytochemistry 72:1358-1370. doi:10.1016/j.phytochem.2011.03.016

Zimmer, A.R., B. Leonardi, D. Miron, E. Schapoval, J.R. de Oliveira, and G. Gosmann. 2012. Antioxidant and antiinflammatory properties of Capsicum baccatum: From traditional use to scientific approach. J. Ethnopharmacol. 139:228-233. doi:10.1016/j.jep.2011.11.005 